(Sugden, 1963). Sugden assumed that this bird had escaped captivity and migrated north from some western U.S. zoo.

Because of the possibility that the Manitoba bird had escaped from a zoo or private collection I contacted $\mathrm{Mr}$. J. C. Shaver of the Canadian Wildlife Service in Edmonton, who advised me (pers. corres., June 7, 1971) that he was not aware of any person or zoo in western Canada in possession of live Garganeys.

Mr. Chandler, S. Robbins, Chief of Migratory Non-Game Bird Studies in the U.S.A. (pers. corres., July 29, 1971) notes as follows:

"Mr. Glen Smart of our Endangered Species Program estimates that there are somewhere in the vicinity of 200 Garganeys in captivity in North America. Some waterfowl escape into the wild every year and losses occasionally are very heavy (as during the hurricane season along the south Atlantic coast).... many of the birds are lost without their absence being detected by the owner, and failure to secure documentation of escapes does not mean that escapes into the wild have not occurred. There have been a few reports of Garganeys in the wild in the Middle Atlanic States, and it is quite likely that some of these birds migrate to Manitoba. We have been forced to assume that all such birds have been in captivity."

Although it is not possible to show that the Garganey was a true immigrant to this continent, it is quite conceivable considering the fact that its breeding range in two places almost touches North America and that the Garganey is highly migratory.

\section{LITERATURE CITED}

Delacour, J. 1956. The waterfowl of the world. Vol. 2, London.

Fisher, J. 1967. Thorburn's birds. London.

Godfrey. W. E. 1966. The birds of Canada. Natl.. Mus. Can. Bull. No. 203, Ottawa. $428 \mathrm{pp}$.

Robbins, C. S., B. Bruun, and H. S. Zim. 1966. Birds of North America. Golden Press, New York.

Sugden, L. G. 1963. A Garganey duck in the wild in Alberta. Blue Jay, 21:4-5.

\title{
FIRST RECORDED TURKEY VULTURE NEST IN RIDING MOUNTAIN NATIONAL PARK, MANITOBA
}

\author{
by E. W. Andrusiak, D. C. Harbottle and K. R. Whaley \\ Riding Mountain National Park, Wasagaming, Manitoba
}

The Turkey Vulture (Cathartes (uura) is listed as an "occasional casual visitor" in Riding Mountain National Park by Taverner and Sutton $(1940: 4)$. Soper $(1953: 15)$ did not observe this species during his faunal investigations in the park from 1940 to 1946. Godfrey $(1953: 8)$ did not mention any Riding Mountain records although observations from Duck Mountain and Dauphin, to the north of the park, are listed. Godfrey (1966: 85) also reported nests on the Duck Mountain, on Elk Island in Lake Winnipeg, and at Long Lake north of Whiteshell Provincial Park. Long (1971) reported 12 known nests from Saskatchewan, including Madge Lake on the Duck Mountain. Blood (1964: 204) listed seven observations between
June 15 and October 20, 1962 and three observations between May 4 and September 17, 1963, including several pairs, at Riding Mountain. Since the latter observations there have been numerous sightings of Turkey Vultures in Riding Mountain National Park by the warden and naturalist staff.

On June 2, 1971 a nest was located on a fairly large island at the north end of Baldy Lake. Baldy Lake is 16 miles north of Oakburn, Manitoba and 2 miles within the park boundary. A vulture was first sighted from a fire tower which overlooks the lake at its south end. It circled the lake and disappeared. Upon investigation of the main islands in the lake this or another vulture was flushed from the nest. 


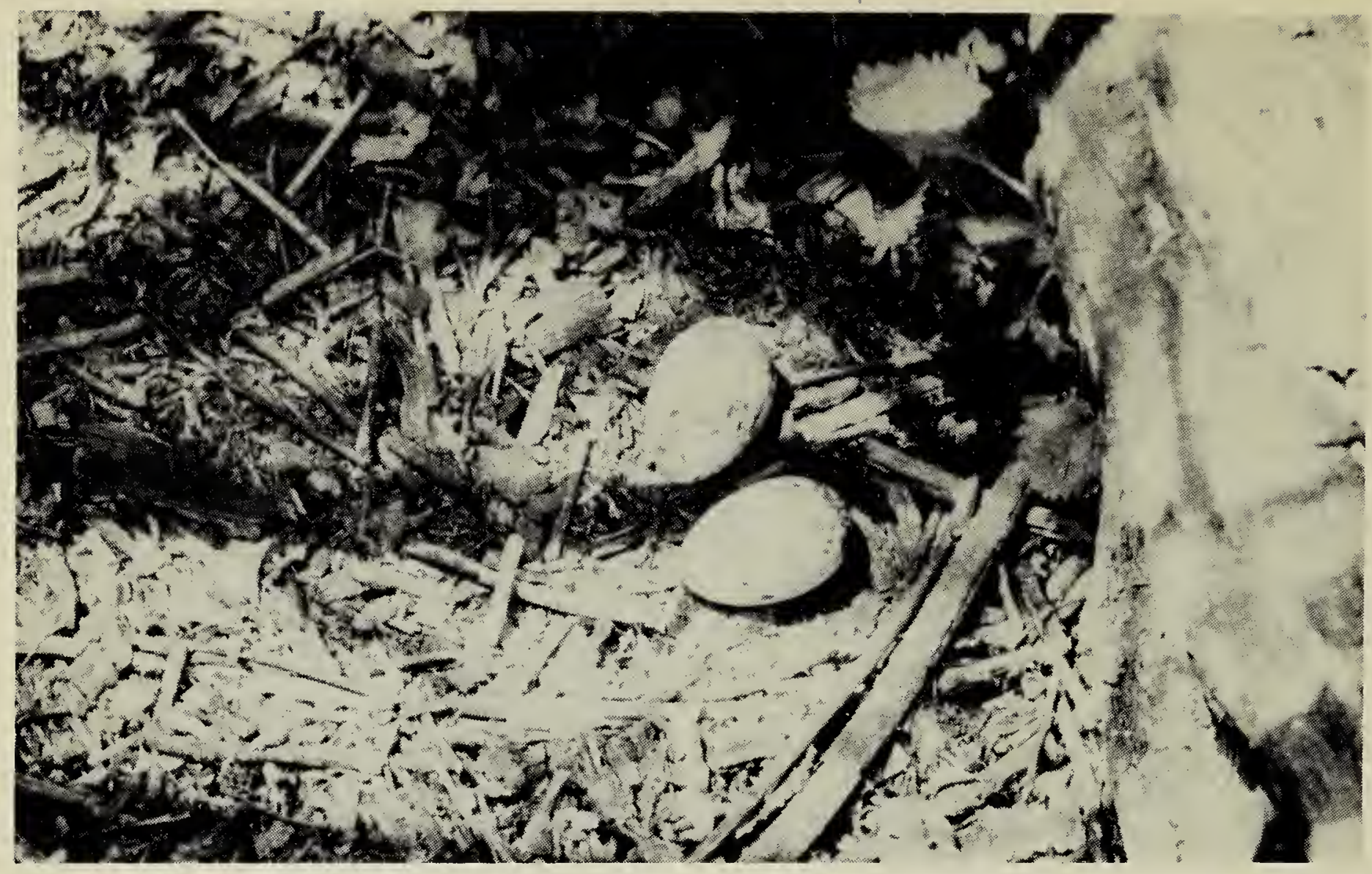

Turkey Vulture nest on island in Baldy Lake, 1971

The nest site was located on a gently sloping hill among willows, ferns and white birches. A wet sedge meadow was located at the base of the slope. The two large greyish eggs, speckled with brown, were situated on a crude bed of decaying wood chips which had been torn from a nearby rotting limb. The nest was protected on three sides by overhanging dead branches. It was accessible through a single tunnel-like east entrance. During observation of the nest both adults circled overhead.

We extend special thanks to Park Warden H. L. Jennings who first noticed the vultures at Baldy Lake on May 20, 1971 and the Chief Naturalist R. J. Walker for assistance in preparing this article.

Editor's Note: Herb Copland, Manitoba Museum of Man and Nature, reports that Nest Records Cards record a Turkey Vulture nest found by $R$. W. Sutton on May 12, 1957, at High Lake, Manitoba. The nest containing two eggs was in a cavity formed by large blocks of granite on a cliff on an island. The nest, deeply lined with leaves, was at the back of the cavity where the two entrances met at right angles. The location of the nest in 300 yards from the Ontario boundary of Manitoba.

\section{LITERATURE CITED}

Blood, D. A. 1964. Notes on the birds of Riding Mountain National Park, Manitoba. Can. Field-Nat., $78: 204$.

Godfrey, W. E. 1953. Notes on birds of the area of intergradation between eastern prairie and forest in Canada. Nat. Mus. of Canada, Bull. 128. pp. 189-240.

Godfrey, W. F. 1966. The birds of Canada. Nat. Mus. of Canada, Bull. 203, Ottawa. $428 \mathrm{pp}$.

Long, R. J. 1971. Photographing Turkey Vultures at Madge Lake. Blue Jay, $29: 86-87$.

Soper, J. D. 1953. The birds of Riding Mountain National Park, Manitoba, Canada. Can. Wildl. Serv., Wild. Mgt. Bull., Series 2, No. $6,54 \mathrm{pp}$.

Taverner, P. A., and R. Sutton. 1940. Preliminary annotated list of birds, Riding Mountain National Park, Manitoba. Natl. Mus. Can. Mimeographed manuscript.

\section{NEST RECORD CARDS}

Please send 1971 Prairie Nest Record Cards in to Mr. H. W. R. Copland, Manitoba Museum of Man and Nature, 190 Rupert Avenue, Winnipeg 2, Manitoba, as soon as possible, so that the 1971 summary can be prepared. 